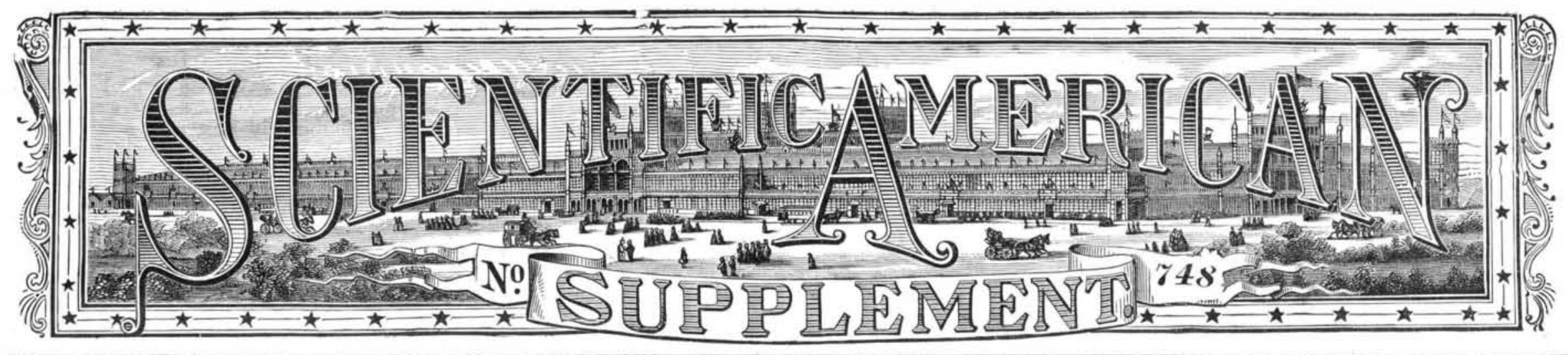

\begin{tabular}{l}
\hline Scientific American Supplement, Vol. XxIX. No. 748. \\
Scientific American, established 1845.
\end{tabular}$\quad$ NEW YORK, MAY 3, $1890 . \quad$ \{ $\begin{aligned} & \text { Scientific American Supplement, \$5 a year. } \\
& \text { Scientific American and Supplement, } \$ 7 \text { a year. }\end{aligned}$

A SINGULAR ELEVATOR ACCIDENT.

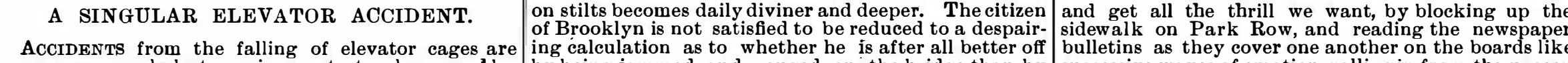

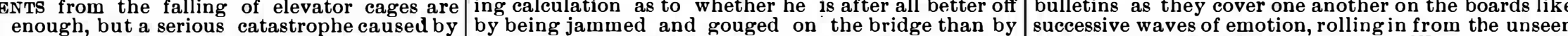
the ascent of the cage is rare. A terrible accident of balancing on one trodden toe upon the old ferry boats but tangible, throbbing distances. We know what this nature occurred in the mines at Drocourt, France, before he can reach his little vineclad, mortgaged home the past was. The blizzard of two years ago brought men, was rising very rapidly when the man in charge, man, it is needless to say that of all the ills of his weari- savagery in locomotion as it prevailed prior to the wishing to apply the brake, foind to his terror that it did not operate. The cage mounted to the enormous Still, we are infinitely better off in choice of location all the glamor of the romancist to be made even tolerviolent shock, and the cage was partially destroyed, fore us, who knew not the elevated railroad, and never Pullman special for the South, and has had his pleademolishing the iron fram

leys.

Two foremen were killed workmen died a few hours later, and nineteen other were more or less seriously
injured. Oniy three escaped unhurt. Delcolle, the man in charge at the time of the acrest. To clear himselfh claimed that the brake wa in bad condition, as the been changed some days before by order of the adquantity of water wust inder, preventing the cy ration of the machinery. comrade who had the incomrade who had the intwenty - four consecutive hours, and finally that he increase th speed of the cage when carrying up workmen or fense had to be left to the investigation of the coronor's justre.

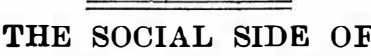
THE E LECTR IO RAILWAY.*

By T. C. Martin.

A MONTH or two ago we had the pleasure of listen ing in this hall to a most Dana Greene on the development of electrical trac
tion. I had previously promised the secretary of the society a paper on the would be useless for me to traverse the same ground again. Mr. Greene spoke with authority, and not as one of the newspaper learn from him and accep recognize the fact, however, that hedealt with the topic mainly on its technical side, as a specialist of experience, and that portant branch of the subport ant branch of the subful words might be saidnamely, the relation of the lic and to social condition generaliy.

Few of us stop to think

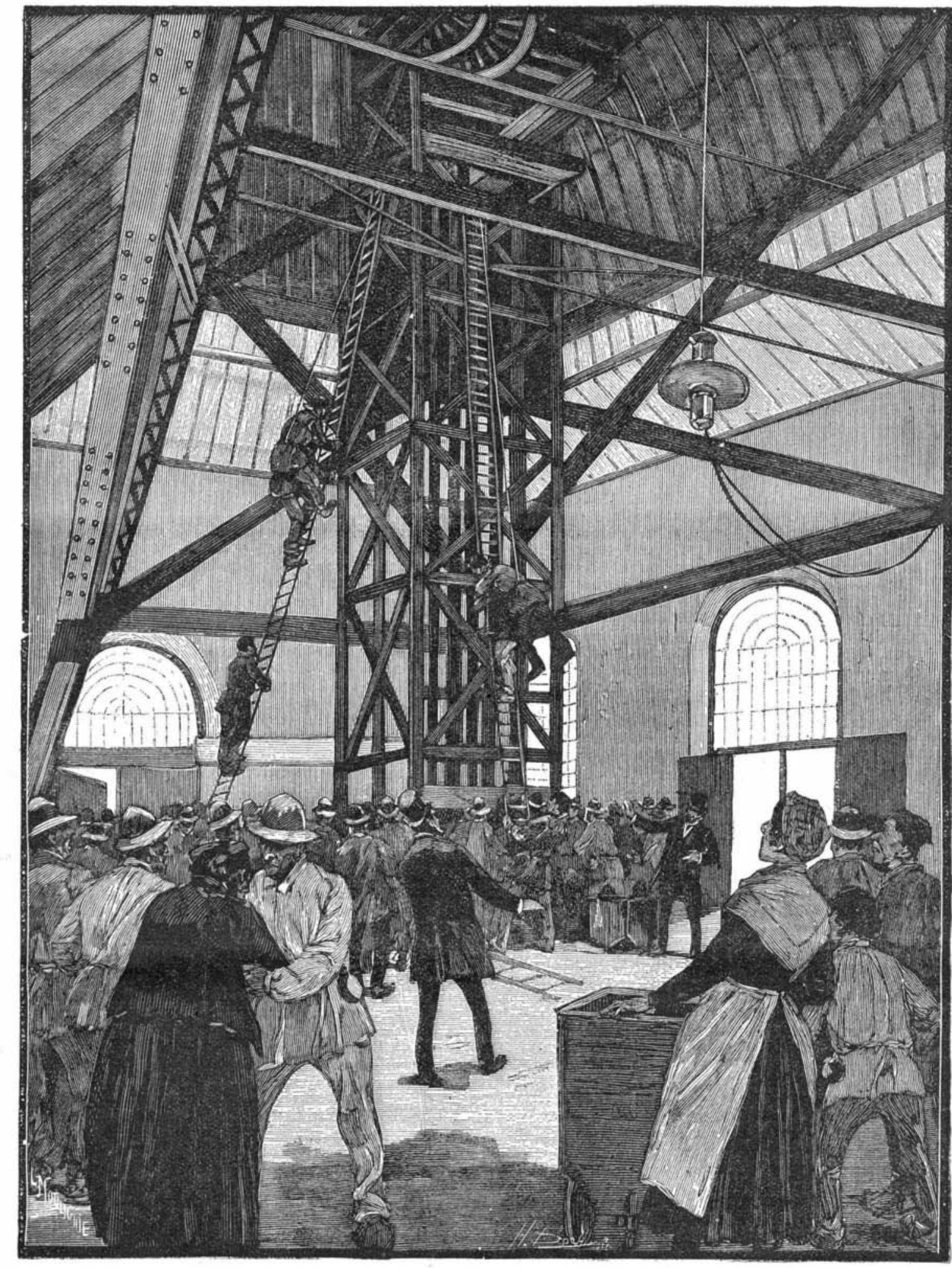

A SINGULAR MINE ACCIDENT AT DROCOURT.

sure in Florida, and re turned, before the storm
that was in progress when he left has gone eastward What steam has been to long distance travel in replacing the stage coach in turn to urban travel in the cable road. Later in this paper I will indicate tricity may sooner or late realize the best and brighthalf of the transcontinental steam railroad; but our first thought is as to elec in which it affects socia relations, by modifying as
with the harlequin wand of transformation all the have heretofore been subjected.

In speaking of this great advance of electricity as converience of man, I do as praising a perfect thing. We are in the early stages of practical electric locomotion. The pioneer work has been done by young
men, still among us, much too near their salad day to fall into the reminiscen years ago that I had mybefore the American Instithe first statistics publishrailways, with brazen audaity upon every bit of a track that sion as a road. I would be understood rather as appearing in advocacy of an spects crude, but which is not yet appreciated even electrical industry have a great duty in this respect, of preaching the advantion, in season and out of season ; and by our persistency we can help the art along. The phrase that good wine needs no bush American advertiser, and the idea that electricity will make its own way is of any great invention that $h$ a s y e t subserved the needs of mankind. Electric locomotion is, howthat facilities for travel make in our lives. I do not gladdened their eyes with the majestic spectacle of the an opportune moment. It offers itself at a time when refer to the opportunities and appliances for long platform of Brooklyn bridge at a quarter to six on a everything else that has been tried for urban travel has that we calmly accept as a prime condition of will take the trouble to invite the candid opinion of realized because of our higher conceptions of what existence. It is probably safe to say that every one of the "oldest inhabitant" as to the vanished Broad way such travel may be. It is a singular principle that as us came here to-night, and will go home, without stages, the early street cars, and the ancient ferries, a system or devicereaches perfection, something comes depending on our legs to make the trip. But this is you will learn that we have scored a distinct advance. forward to supersede it. The horse coach was at its altogether modern, and to the generation immediately
preceding ours would have seemed as unlikely as that, Thy we all want something better. from total lack of exercise, our legs should become toretaste of the civilization that awaits our descendants. atrophied and own no function of pedestrianism. Yet We are beginning to learn that luxury is a relative quering steamship. And so to-day, the horse, the now that we have enjoyed the advantages that the term. A hundred or even fifty years ago there was no cable, and the steam locomotive have shown the utmost means of artificial locomotion already gives us, we such thing as luxurious travel. Washington came to that they can do, just as the electric motor rolls to the want more. The Harlemite does not consider it rapid New York to be installed as president, in a manner front and takes the stage, as the means best suited to transit unless he goes from City Hall square to the that a fastidious drummer might now despise. De the peculiar requirements of passenger traffic in mod-

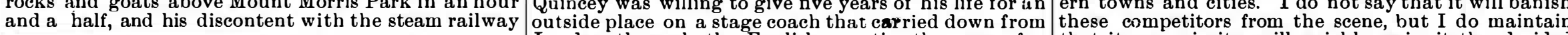
London through the English counties the news of a 2 that its superiority will quickly gain it the decided *A payer read before the New York Filectrical Society, March 12, 1890. great event. We save our five years and our health, preference. I aw always suspicious of an in vention or 
improvement that is going to knock out every thing
else, like a charge of dynamite. History is against any else, like a charge of dynamite. History is against any whe antecedent methods and appliances to the sphere The old is restricted to its proper place and function as by a ring of fire the new goes on making its own fulfills himself in many ways, lest one good custom should corrupt the world." direct notice is the effect on the public of the adoption
of electricity as a motive power for street railways.
The struggle for supremacy in urban passenger work The struggle for supremacy in urban passenger work
has already narrowed down strictly to the horse, the
cable, and the electric motor. As everybody knows, steam motors are completely out of favor for use within
city limits. T'heir glorious record of half a century in long distance travel does not deceive any one dwelling in a city as to the insuperable defects and nuisances of
noise, smeell, smoke, dust, stean escape, oil drippings,
etc., which may be more readily tolerated, remotely. etc., which may be more readily tolerated, renotely: lieve we shall not see any more steam roads in New York, and that, imposing as are the statistics of the eclipsed in a very few years by those of the newer form
of electric locomotion. And may not the same be said of electric locomotion. And may not the same be said
as to the horse? There are now close upon 15,000 horses engaged in hauling street cars around this city. with, as well for its own sake as for that of the city, it aids in driving into exile.

Allowing an average space of 40 square feet to each
horse, or a stall 9 feet br 41 feet horse, or a stall 9 feet by $41 / 2$ feet, we find that in stall
space alone those 15,000 horses occupy 600,000 space alone those 15,000 horses occupy 600,000 square the car if every car were in commission at once, which
is not at all the case. But even if nearly all the cars were wanted, an average of 10 horse power each would
be ample in the central station of an electrical plant to bring us a liberal allowance of 25,000 horse power.
But here comes in the remarkable though not unBut here comes in the remarkable though not un-
familiar fact that a steam plant will go into much less space than an animal power plant of equal capacity.
Mr. C. J. Field, who is known to many of you as a constructing and mechanical engineer, informs me that plant for 20,000 horse power, to operate all the street cars of this city, could easily be placed in a building
100 by 150 . The engines and the dynamos would be
placed on the first floor, and the boilers on the second floor. The generaters in such a plant would be multipolar, 500 horse power each, directly connected to the
engines, and each would be of a vertical triple expansion type, of 500 horse power each. This gives only $11 / 2$
square feet to the horse power, and we may offset the space for feed, etc., by that for coal, etc. I have tested
these figures by those of recent electric light stations and reasonable. It might be objected that all the
power would not be bunched in this way; but even
with half a dozen geuerating stations of 2,000 horse power, there would only be an increase in space re-
quired of about 10 per cent. From this remarkable quired of about 10 per cent. From this remarkable
but strictly proper comparison, we can form an idea as
to the economy of real estate, bearing in mind also the fact that horse car stables are generally wooden or brick sheds, only one or two stories in height, while an
electric plant yay be run up as high as an appartment house or an office building, just as ornate without, just as clean within.

Hence there can be no mistake in the statement that
electricity is a direct boon to the urban population electricity is a direct boon to the urban population
that clings to the city, loves the city life, and that, if pangs of banishment: Indirectly, too, it is a further boon, because with horses a great portion of the dis-
trict surrounding the car stables is also spoiled for hu man habitation. "The whole region within what I would define as "the area of smell" is unsavory and
unhealthy the year through, and the consequence is
that while the taxing and renting value of it is lessened the death rate is run up. "Do not insult a respectable animal who has come from the country to do his share
of the work of the world," says one authority, "and has brought with him the memory of the sweet hills and skies, at least, by immuring him in one of those where a dumb beast would lose his self-respect and his courage beneath an oppressive weight of miasma and
hideous, gloomy, nasty confusion." And so say all of
us, and all of us are glad to note a vast improvement in this respect. The stables are better ventilated now,
as a rule, but the trouble is just there. If they were as a rule, but the trouble is just there. If they were
not so well ventilated, the neighborhood would be
sweeter and would be fitter for human beings to live sweeter and would be fitter for human beings to live
in. The poor die quicker, that the horses may suffer An objection I may anticipate is that, after all, such
large generating plants would notbe desirabler with large generating plants would notbe desirablet, with upon the atmosphere, their receipt of coal and their
removal of ashes. I would reply that it is by no means right upon the main lines of travel. They would, by decided preference, be located near the water's edge,
out of the way. Moreover, the stacks would be, as
they are to-day in large electric light plants, high enough to carry off all smoke or smell far beyond perception. Perhaps the familiar smoke stack is not an
msthetic object, but it can be made so. There are
steeples in this town that, on the score of their beauty, are not fit to compare with smoke stacks near them. Much that I have said under this head with respect
to electricity applies to the cable. That system has
been an immense advance in street car travel, and is of much praise, but it will not hold its own with elecof nuch praise, but it will not hold its own with elec-
tricity, simply because it is deficient in some things
that electricity possesses to a pre-eminent degree. has been a forerunner for electricity. It is not only enormously costly in its first installation, hut has the with in the idea that to rise with the lark or go to bed enormously costly in its first installation, hut has the with the sheep is a popular fallacy. There are still
disadvantage of being a unit. The whole of the road fewer of us who, even for the sake of rural delights,
and all its power hangs a by that one cable. If the cable care to isolate and immure ourselves in remote suburbs be duplicated in the conduit, the expense is again so stands. Moreover, a cable car cannot go back ward at its driver's will. Onward it must go, Mazeppa-like,
strapped down to its carrier, no matter what unfortu-
nate contingency impend, or what obstacles lie in it path. It cannot greatly vary its own speed. An elec-
tric car is so manageable that it will reverse in its own cable is that it is always the one thing, while there
are very few towns or cities that are alike in offering just the rigid Procrustean conditions it meets. There
are about 50 cities in the United States with a population of over 50,000 , but there are between 700 and 800 all the places in the first category could justify the heavy expenditure on a cable system, there are hun-
dreds of others unable to do so. We need not wonder,
then, that at their last convention in Minneapolis the street railway men gave electricity such a hearty wel-
come, adopting the enthusiastic if not elegant lan-
guage of a committee report, which said that it "filled guage of a committee report, which said that it "filled street rail way company in Minneapolis has just thrown
aside an unused cable plant that cost $\$ 400,000$, and is
putting in electric Why does electricity "fill the bill," and in a manne Why does electricity "fill the bill," and in a manner
that interests the public? Well, for the reasons given plastic, protean. It can be applied in half a dozen different ways, and be absolutely safe for human life in
any and all of them. The street railway may be
equipped with an overhead system for supplying the current to the motors, and to that system, well
built, with trim ornamental poles, lines well run and guarded, little or no objection ean be offered. The air is tonians, who are people setting no small store by their
refined, acute, and cultivated taste, have adopted poles work tunnels we have in New York to hold up our elework tunnels we have in New York to hold up our ele-
vated roads, and I admire them for it. It is possible
that Boston may have an elevated road, but if so it will be a handsome electric one. Or, if the overhead
wire be objected to as it may, there is the conduit system, which is fully able to give a good account of itself the that the wires are not exposed in the conduit sys may between it and the overhead methods. There
maysulties in heavy, wet, or snowy weather, but we shall see them all overcome. Or should this or its modifications again be found fault with, there is th
deal storage battery system, where each starts out "
its own hook," an independent, self-contained unit. don't exactly know why we call it the "ideal system." it is either within reach or beyond. " "within reach,
it is not "ideal," but ought, speaking from the public
standpoint, to be adopted wherever there is actual need or it. It may be a trifle expensive. but that is certain-
ly not one reason more why the public should do withy not one reason more why the public should do with
out it. It way be somewhat difficult to put and keep
in order. "Gouches, Sammy," said the elder Weller, sententiously, to his son, "coaches is like guns-they
require to be loaded with werry great care afore they go off," and that is about the case with the storage
battery cars. But they do go off, and we know from the approval they have met with that they do hit the
mark of popular approval, and that is one of the main
things I am talking about to-night. It is in one or other of these systems or modifications
of them that electricity will become familiar to the
public of this country in street railway work. It will, think, be chiefly for a long time to come the overhead
system, which is not costly to put up, is nor expensive to maintain, can be operated economically at about
half the running charges of animal power, and fully nswer the requirements of the vast majority of ou All these methods are safe, and none of us ever heard,
or expects to hear, that the currents of 500 volts they have employed have taken a single human life. The
motor cars cannot "explode," the daily papers to the contrary notwithstanding. they are pleasant to ride in, and they do not damage operation, and naturally make their worst showing on ways in this city. But the roadbed between the tracks
they never touch. It might as well be a continuous plot of flowers. In the outskirts of Boston some of the
electric cars whose aerial wires run hidden between the overarching trees have their tracks laid down in a though the cars were gracefully skimming over the poised swallows.

I have just spoken of the outskirts of Boston, an goodric cars are an element making for the public
goolp a man to get further away from his business, and yet bring him nearer to it. "Rapid transit," by their means, is no longer a deceiving phrase,
or the proud monopoly of one or two big cities. The
smallest city in the countrs is at once given a command it never had before over the territory around it. The
mallest storekeeper or the humblest clerk can revel in the sweets of rural life if he wish. will give him more of home life, a few more golden
minutes with the children in the morning, an earlie return to the wife at nightfall. The whole social atmo-
sphere of the place is vivified and the social bonds are $\mathrm{knit}$ closer, as they always must inevitably be where
the facilities of travel are increased and the opportunities of intercourse are mult iplied.
Nor is this all. Rapid transit of this nature opens up number of distriets that before were practically inac who eare to practice the ancient form of dissipation heap, and a wire is well insulated up aloft. The Bos

They scatter no dust or ashes; they do not litter th reached with difficulty. ness of the woods, or the solitude of the mountain, that
we may commune with nature and hear the still, we may commune with nature and hear the still, the world's work 50 weeks in the year, we want to be man lives in the city, he pays a high rent and takes out, and wastes his time in travel, he is in hearty sym-
pathy with the eight hour movement. I look upon electric roads, therefore, as likely to prove a beneficial
agency in the more equal distribution of a happier population around any center, thus increasing the renent of retail trade, enhancing the profit of the area ying within the region thereafter more legitimately
restricted to business occupancy. I have watched with already thus developed suburban areas. Booms are inay be, and not unfrequently are, genuine and real, tate boom of the best character with permanent results
than the installation of a well-rnanaged electric road,
enabling a man to leave his work at six o'clock and be sitting down to his supper seven or
wish, under his own rooftree at $6: 30$ Having thus discussed the effects of electric roads
Havis the community and on the individual citizen. I will add a word as to their effect on the wonderful impersonal entity, " capital." If all that I have said be true as to I refer to now is not the direct enhancement of values,
so hard to trace out, though so palpable, but the stimulus given to saving habits by the better opportunities
lof investment. Careful analysis of the working of electric roads goes to prove that when operated with
skill and discretion they are fifty per cent. less expenskill and discretion they are fifty per cent. less expen-
sive to run than horse railroads are. What does this mean? One thing it means is that many roads can be Another is that roads not paying can be placed on a
Ant of In 1888 out of nineteen horse roads reporting in New York City, ten showed a deficiency. Last year their may be of fertilizers. A third point is the establishing may be of fertilizers. A third point is the establishing
of a ne w class of investments of a solid, enduring nacumulation of capital tends constantly to the red uction
of interest to a minimum. There was a time when the long stocking and the iron chest were the common
bankers for the savings of the timid; and the capital and scarcity. the English people have always wanted to put their and this is undoubtedly one reason why English capital, free and fluent, is so much a power in the finance
of the world, and why so much comes this way. As
Mr. Bagehot says: "In most count ries most men are content to forego interest, but in more advanced countries at some times there are more savings seeking inis thus in America, so far as "safe" investments are conctive care and ceaseless thought of the capitalist, but may be held by trustees widows, hospitals, universi-
ties, savings banks and the like. The competition of capital for the best class of governinent bonds, munici-
pal bonds, railroad stocks, etc., has red uced the earnings on these to a very low figure, whether in America,
or England, or Germany; and the result is that we see to-day, as never before, the planning of enormous ent in no small degree the endeavor of eapital or savNow, I look upon the street income, but in newer fields. cow, I look upon the street railway business of the
country, under the regime of electricity, as offering one may be called the organization of local savings, which might otherwise lie around in napkins, like the unjust
steward's talent, and be of no use to anybody. The capital in street railways in America to-day reache If the statement I have made as to the superior econo-
ay of electrical power be true, how much greater becomes the earning capacity of this investment, how much greater are the attractions held out to construct
the hundreds of new roads that are still wanted and will. be called for as our towns and cities grow. Of
course, I am a ware that it may be said that this showing might lead to a demand for lower fares. It might, things are more necessary, such as better cars, with running time and shorter head way, so that the fifteen hundred million passengers on the street railroads ever roads are peculiarly suitable as a field fort. Street rul investment. Their operation can be watched all the time. They his window when he is home. He knows something of their officials; he can influence the domestic legislation
they are subject to: he can assist in more ways than The next important point to which I would direct your attention is the elfect that the electric rail way
has upon the employes of the service. It cannot be
denied that the introduction of electricity in this respect marks a decided advance in the social condition and aptitudes of a large body of men. I have never
yet met with anybody or anything that could place the
work of a horse car driver in a favorable light. One certainly could not fairly expect a man who spends ize a very high ideal of life and duty, especially when the whole of the work is done under conditions ex-
hausting alike to temper and physique. It is outdoor exposure the whole time, whether in sumber heat
or winter blast. Half the time it is an exercise of sheer brute strength, and no car driver believes in his heart that $a$ horse wrists and dislocated shoulders tell hmu that Watt was far below the mark in putting it at that tigure. And
then the worry of the street traffic. We have all of us 
men and coachmen will keep on the car tracks in front of a car. An investigation made two or three years ago in Chicago showed that at one point in the streets while at another it was $871 / 2$, at a third 90 per cent.
Against such odds the driver, with his restless or Against such odds the driver, with his restless or
apathetic team, has to make his way and keep to the running schedule; fighting all the time with the fear
of an accident either to his car or to some hapless foot Wassenger. and brawn, but of average intelligence and ordinary and forthcoming, or the same men are relieved from
physical wear and tear, and thereafter can earn their
bread in the s weat of their brow and not that of their body. A woman might easily run an electric car. The the exact degree of power that he wants; he can apply his brakes readily, and if he needs to run backward up
hill he can do so sitting down at his switch. It is not necessary to expose him to the weather. His fears as gain in control of the car and by the further fact that an electric car takes up only half the space on the not less safe than cleanly. You may remember that
when steam roads were started in South Carolina, one of the negro drivers ried down the safety valve and
then sat on it. As a result, cotton bales were placed between the locomotive and the coaches to protect the passengers in case of explosion. The new driver was,
however, still on the wrong side of the bales. In electric cars both driver and passengers are free from harm. was a first class carriage in an express train; but to-day it may be fairly affirmed that no vehicle can compare A feature of this refinement of the work is that it must necessarily be attended by better pay for the
hoes not colligence and skill. Mere brute strength does not command good wages nowadays, except in a
prize fighter, and the further we get away from animal conditions the better do we find the status of the individual or the occupation to be. The remarks made
above as regards the drivers apply equally to the statf why there are so many hostlers around car stables, but when you remember that well kept car horses work they need a good inany attendants at the stables dur-
ing the other twenty odd hours. In place of these grooms and hostlers you have, with an electric plant, a skilled force of steam engineers and mechanics, each of the division of labor has shown him to be best qualiAnd here let me inject the pertinent remark that
this new and successful development of electricity is this new and successful development of electricity is one reason more why the mechanical engineer and
steam engineer should master electrical principles and practice whether for the high walks of his profession
or for the humbler duties of running a plant. The eoming of electricity and its application to light and
power have afforded a grand stimulus to steam engineering in every department, and may not improperly be
claimed to have created the modern high speed encal engineer is nine-tenths a mechanical engineer. To this I will add a corollary, and say that the unechanical if he will only add the one-tenth to his education. The time is at hand when the inechanical engineer will not be considered worthy of his name or his calling un-
less he is also an electrical engineer, as familiar with Ohm's law as he is with Carnot's or Mariotte's.
Incidentally through this paper I have referred to the effect of the electric railroad upon horses. It has, indeed, been most gratifying to see how readily the mane Society. It is a humane society itself. Whether
he wished it or not, the electrical engineer in this instance is conferring a great boon on the horse. We sometimes do the greatest good, as we do often the pose; and so here the inventors of the modern electric motor and the electric car have released the horse
from one of the most painful and exhausting services that it was ever put to. Investigations over a long
period have shown that with the pavement dry a horse would meet with an accident in every 78 miles of travel and every 537 miles with the pavement thoroughly
wet. Unfortunately for the horse. though happily for the rest of us, the first two conditions generally prevail
on our streets, and hence the horse has a poor outlook as to accidents. But it is not tlie accident the horse
has so much to dread, after all, as the constan'strain has so much to dread, after all, as the constan's strain
and the pull of a heavy load from its dead rest every railway men that car horses fail because of this feature of their work, and that it helps to cut down their railroad life and utility to the average of from three to
five years. If you want to see these conditions at their worst, take Broadway, once our pride, now one of the
most overrated thoroughfares in Christendom. The pavement is abominable, and the horses, like the foot
passengers, can be seen struggling for a grip on the uneven, slippery stones, all the way from one end of it to the other. The traffic on the street is so great that $I$ from dead rest between Chambers and Barclay streets two blocks. It does not require an expert to forese cinnati, recennig, on installing an electric equipment, a
street railwa3 company advertised its horses for sale for family and carriage purposes. I have not observed railway managers are more modest or more truthful only persons likely to regret seriously the departure of the street car horses from this eity would be horse
dealers and feed supply houses, and possibly the street

how. pracementof a certain amount of labor in an elementary form, whether that of the horse or the human being motor car driver, but in the electrical expert and in
ventor. Society benefits greatly by this, just as it does by the superior skill and efficiency i mplied in the main-
enance of such a system as that of the Pennsylvania Railroad Company. The running of express trains and ast steamships demands the exertion of the best qualiprovement as in the details of solid construction and
vigilant management. Here, therefore, we strike a once into a new field of design and invention-one that promises to be as large and fruitful as any other known
to the application of electricity. There have already
been several hundred patents taken out on the specia been several hundred patents taken out on the special withrumors of the ideas and inventions assuming shape. own father. Each new step is a prophecy of a dozen more. Each new patent is a "father of its country," erm of endless fertility. We begin to learn our re
ources. "Is there any load that water cannot lift ?" asked Emerson. "If there be, try steam, or if not that
try electricity. Is there any exhausting of these Now and then I hear the objection that people would be the quicker to adopt electric locomotion if it wer not so beset and made costlier by patents. This is not
true and I have no patience with the spirit that begrudges the inventor his reward. Why do we use the
reat inventions? Simply and solely because they ffect an economy for us in some way or other, chiefly in time or money. If they did not, we should care lit-
tle about them, and the inventive geniuses of the day would be mere common clay to us. But, on the conencouraged by the wealth and fame he can earn. the inventor is wanting in public spirit and devotion
to science because he takes out patents and does not nvite the world to revel in the riches he reveals while he is content to starve over a crust in a garret. A few
eeks ago, Mr. Edison told me that he had found one of his greatest intellectual pleasures in reading EvangeEdison to secure a patent on his phonograph than for Longfellow to obtain a copyright on his poetry? Why
hould not Bell have a patent on the telephone when ictor Hugo protects his Notre Dame? Is it not as come from his life saving air brake as for Gilbert \&
Sullivan from their comic operas? Shall not Elihu Thomson enjoy some revenue from his new art of elec-
ric welding, as well as Bronson Howard from his Shenandoah? It is time that the ideas on this subject ists, the poets, the musicians, and the artists, they are
public benefactors. They promote the public welfare, public benefactors. They promote the public welfare,
and to the public comfort, increase the public wealth.
The field of electric locomotion will be but one more opportunity to demonstrate this truth. There is no
patent on the horse, but the patented electric motor patent, on the horse, but the patented electric motor
can beat him on every point every day in the week.
Such, then, are some of the reflections to which subject invites us, at this early stage of its develo ment, and there is but one other point to which, after this section, I shall refer in closing. Before I leave the the outset, that I a ni not presenting this latest appli-
cation of electricity as perfect. It is not; on the contrary, it is in development and iruprovement under our
very eyes. It is endeavoring to harmonize with its environment. The questions and probleins that it opens
up are very much like the concentric shells of the Chinese ivory puzzle balls; and we bave not yet reached
their core. It has one or two fanuily quarrels on hand. their core. It has one or two family quarrels on hand.
The telephone is hardly yet on speaking terms with it.
But we know fairly well where the solution of each diffi culty lies, and we are on the way to it. Nor am I in any sense an apologist for the shortcomings of our pioneer work. Electric railroad men have made mistakes, are
making them now. That cannot be belped. Heaven save us from the men who cannot make mistakes, they will never learn. The conditions in electrieity as an in-
dustry change with lightning rapidity. A Russian gentral Asia that it changed every minute; and so it is in regard to the onrush and uplift of electrical discovery
and enterprise. This very fact explains why much of the earlier electric railway work has been of an un-
finished, unkempt kind. Mr. Charles Francis Adams, some years ago, in his interesting little work on railhat almost uniformly those early railroad builders
nade grave blunders whenever they tried to do their work peculiarly werl, they almost invariably had after-
ward to undo it." This is not an excuse, however, for slovenly work. It is better to make blunders trying
to do well, than in lazily neglecting one's duty, and though it hurts a man who built for eternity to see his ing consciousness of right effort and honorable perormance. The electric street railway will the sooner achieve its social destiny if the engineering done upon
it be the highest and best that the art at each instant The topic I have reserved for brief final mention is partment of the subject in which imagination has not et sobered down into invention. Our fancy still plays social side of teletravel, people have not yet awakened generally to the idea that it has any serious practical
side at all. Our patriarchal poet, Whittier, expressed surprise a month

"Far more than all I dared to dream.

Un sought before my door I see;

On wings of fire and steeds of steam
The world's great wonders come to me."

The steeds of steamare now an old familiar story, but the mechanical Jay-Eye-Sees of the coming day mating that of light. It is amusing, however, to see how quickly our generation has become accustomed to eletravel. Did not the royal college of Bavarian doc
ors seek to forbid rall way travel because it would in duce delivium furiosum among the psssengers, and
drive the spectators crazy? Did not an English quar- erly say: "We would as soon expect the people of wich to suffer themselves to be fired from one of of a machine going at the rate of twelve miles pe fter a railroad journey with ladies from Boston to er caste, let a lady move in select company at five miles an hour and take her meals in comfort at a de have a familiar sound, perhaps, but I can assure you that they are positively of the ancient date mentioned, he fact remains that to-day we have a speed of sixty miles an hour in rail way travel as ex
traordinary, and are casting about for the means with which to attain a higher rate even than seventy-fiv miles, of which record was made in 1886, on a short
run. This acceleration is, it appears probable, to be
found best or only in the use of electricity, for the reaon that the electric motor maydrive directly on the or smash the track, and that it does not have to carry tive making with ease 120 miles an hour, and who propose to propel it at 180 miles an hour. If these things ravel the public will have to accustom itself to strange
new conditions, exceeding. in scope and power, those of the last fifty years. The change will come in our
time, and the present telegraphic and telephonic facilinstantaneously with friends in Boston or Philadelphia over a wire, we resent the inadequacy of the means of
fast and far locomotion that should enable us to meet them face to face if we wish to do so. When we see
electric cars in our streets traveling easily fifteen and twenty miles an hour, and know that on a clear un-
broken straightaway track we could go from New York o Philadelphia or Boston with the same agency and kindred apparatus in about an hour, American ingenuity and enterprise will not rest until the thing is
done. That will be the first stage in the next evolu At the present time electric street railroads are run-
. with ome 2,000 cars on about 1,200 miles of track. So far as urban traffic is concerned, the new departure has been made. Electric locomotion is with us an aselectric light is of illumination and the telegraph or
telephone is of communication. Already over 100,000 . the welcel ballots are being cast yearly in its favor, and
the welcome to is universal. In the Northwest that brand new cable plant costing $\$ 400,000$ has just been
thrown aside to make room for it. In the South it is saluted with the exclamation of the delighted darky,
"First dey freed de negro, and now dey freed de male." In New York we are waiting on Providence and the
aldermen, but we shall not be satisfied till this city is which has given, in so short a time, so many proofs of ts ability to promote in every respect the highest social welfare of the citizen.

\section{FLORIDA SPONGES.}

J. J. O'Donnel, in the Florida Times-Union, has this to say of the sponge industry of Florida:
One degree from the northern tropic, Key West, an elbow-shaped island, is the only one of a numerous Flowida for a distance of 200 iniles (Key Largo and a few others excepted); that is inhabited. Its area is The number of houses, including factories, stores and esidences, of which there are many handsome ones, is
bout 5,00n. The unoccupied part is covered ore with shrubbery and underbrush, useless except for firewood. Its geological formation is oolite, which is
quarried in small quantities in blocks of $3 \times 2 \mathrm{ft}$. These hough the Catholie convent is built wholly of this The first settlement in this archipelago of the gulf was made on Key Vaca about the year 1818 hy fisher.
men from Mystic, Conn. In their fishing excursions they found that Key West, from its deep, spacious and roughly constructed homes and betook themselves to Key West, fifty miles farther southwest (the wost southerly point of Uncle Sam's dominions). where they opical sun on the verge of the Gulf Stream.
About the year 1826 immigration set in from the other smaller islands. The two classes soon assimilated, as their polemies and vocations were alike. Fishing was the only industry except when some ocean-tossed mariner got wrecked on one of the many reefs or shoals between Key West and the Tortugas, seventy-five
miles to the westward and also northeast to Cape Florida. These wrecks were numerous, sometime
amounting to as many as two and three a week-forty a year, as shown by the admiralty record in the United
States district court. In November, 1859 , there were
no less than two wrecks on one day, the principal one no less than two wrecks on one day, the principal one
of which was the Heidelberg, laden with 3,000 bales
of cotton, $\$ 30,000$ in bullion and $\$ 10,000$ in specie. Beof cotton, $\$ 30,000$ in bullion and $\$ 10,000$ in specie.
tween the years 1846 (the year of the great cyclone,
which razed every house on the island and scattered to the tempestuous waves Sand Key lighthouse and its occupants) and 1861 , when the first gun boomed over the
ramparts of Fort Sumter, wrecking was the chief medium of getting money. Even now many an anuus-
ing anecdote is related by the first immigrants, and as thrilling as ever warrior told, for sailors, like soldiers, wen were at that time sailors; hence little attention
was paid to the mine of wealth that lay within sight of was paid to the mine of wealth that lay within sight of
their doors, the sponges, the gathering of which has
now grown to be one of the principal sources of The value the place.

The value of the sponge was at that time well known 